\title{
Eco-Friendly and Edible Waste Cutlery for Sustainable Environment
}

\author{
N. Natarajan, M. Vasudevan, V. Vivekk Velusamy, M. Selvaraj
}

\begin{abstract}
Rapid industrialization and urbanization has caused the production of enormous amount of solid wastes. Many nations today are facing environmental pollution due to improper solid waste disposal. Especially, plastic waste disposal has increased rapidly in the last few decades. Researchers are working on safely disposing the solid wastes and recovering wealth out these waste materials. With a view of reducing plastic waste disposal and protecting the health of people, many entrepreneurs have developed an innovative tableware which is edible as well as bio-degradable. This aim of this paper is to review the bits and pieces of work being done on edible tableware in various parts of the world. In addition, the edible tableware developed by individual artists has also been reviewed. The future scope of research in this domain has also been looked at towards the end of this review. We believe that edible tableware could be a potential source for replacement of plastic utensils, thereby providing scope for environmental protection, leading to sustainable development.
\end{abstract}

Keywords : Waste management, Edible spoons, Edible plates, Edible cups

\section{INTRODUCTION}

Disposal of solid waste is a major issue in today's scenario. Many countries are facing massive solid waste management problems due to rapid urbanization and population explosion [1]. Development of industries has supplemented to the sorrow of solid waste management. Open dumping and disposal of wastes in open pits has been a routine process in many places. The accumulated solid waste poses a major threat to the health of various living entities. In addition, the quality of land degrades with passage of time.

The concept of solid waste management and the technology behind solid waste landfilling has been well understood in developed countries [2]. Moreover, the developed countries have chalked out a regulated program for solid waste disposal, while developing countries are still continuing to use unsophisticated methods like open landfill dumping [3]. Waste disposal is heavily uncontrolled and random, and large quantities of them go uncollected in developing countries [4]. It has also been reported that in some nations, majority of the municipal budget has been used for collection

Revised Manuscript Received on December 5, 2019

* Correspondence Author

N. Natarajan*, Department of Civil Engineering, Dr. Mahalingam college of engineering and Technology, Pollachi - 642003, Tamil Nadu, India. Email: itsrajan2002@yahoo.co.in

M.Vasudevan, Department of Civil Engineering, Bannari Amman Institute of Technology, Sathyamangalam, Tamil Nadu, India. Email: devamv@gmail.com

V. Vivekk Velusamy, Department of Civil Engineering, Dr. Mahalingam college of engineering and Technology, Pollachi - 642003, Tamil Nadu, India.

M. Selvaraj, Department of Civil Engineering, Dr. Mahalingam college of engineering and Technology, Pollachi - 642003, Tamil Nadu, India. and transportation of the waste, leaving very little for processing, resource recovery and disposal of the waste [5]. Therefore, there is a growing concern over the improper solid waste management in various countries.

Statistics from the World economic forum cites that the global plastic production has risen from 15 million tons in 1964 to 311 million tonnes in 2014 - the number is expected to triple by 2050 . The average time taken for a plastic bottle to decompose is 450 years. While efforts are being taken to recycle some of the plastics that are being dumped in the open yards, some of them cannot be recycled. Plastic utensils are one among them, disposed off in large numbers, causing severe environmental pollution. Waste production is particularly problematic in large cities whose economic development precedes waste management infrastructure [6]. To combat this even-increasing problem, many researchers around the world have come with an alternative solution, popularly known as edible tableware. Edible tableware is picking up momentum in various countries. With a concern over environmental pollution and degradation of people's health due to consumption of plastic, many entrepreneurs have developed innovative tableware which is edible and also bio-degradable. Edible tableware or edible cutlery seems to the solution for sustainable development and environmental protection in the future. Literature shows that no reviews have been conducted on edible tableware until now. With an aim of providing an overall view of the edible tableware being currently used, this paper discusses the different types of edible cutlery being manufactured and marketed by various organizations. We have also reviewed some of the individual efforts in this direction from an artistic perspective.

Edible tableware is not a new concept. Although it seems to be very new for many, it has been introduced way back in the 1400s. Bread bowl was first introduced in 1427 to impress the British Duke. The Duke was so admired by the innovation that he gave the inventor - an Irish nobleman money to open a bread-bowl shop in city now known as Dublin. Similarly, the Tosada bowl was introduced in the 1930s, made of stale tortilla. The modern bowl - a version of a Mesoamerican design, has since been modified in every possible way, down to the mini Betty Crocker version. Later in the 1980s, the Sourdough boule bowl was introduced in the aim of marketing San Francisco's clam chowder. The Bay area popularized it and the restaurants in USA have used it as a way to charge more for the soup. 


\section{EDIBLE CUTLERY FROM VARIOUS COUNTRIES}

This section of the paper discusses about the edible cutlery that are being used in various parts of the globe. While some of them have been commercialized, others are at the early stages of development.

\section{INDIA}

Bakeys was founded in 2011 by a groundwater researcher, Narayana Peesapathy to produce edible cutlery as a replacement for the plastic cutlery. Plastics are toxic, carcinogenic and they can leech into the food. Moreover, they are not bio-degradable. Around 120 billion plastic cutlery is being disposed every year in India [7].

In a bid to cure this precarious situation in India and around the globe, Peesapathy founded this company which produces edible cutlery (spoons, forks, and even chopsticks) made out of dried millets (jowar or sorgum), rice and wheat. The spoons and chopsticks do not get soggy if placed in water and food. They only soften after some time (10-15 minutes), and can be easily eaten at the end of the meals. Even if discarded, they decompose within 5 to 6 days since they are bio-degradable. The founder seem to have grabbed this idea during a flight journey, when he saw a passenger using a piece of Gujarati khakra as a spoon to eat desert. He also witnessed that the disposed plastics spoons are being reused making them a source for bacterial contamination. Prior to producing edible cutlery, he was working in the International Crop Research Institute for Semi Arid Topics (ICRISAT), Hyderabad, where he conducted research on groundwater. He concluded that growing dryland crops like jowar helps to stabilize the levels of groundwater, and this was the reason why he chose to use jowar for the edible cutlery production. Bakey's production has attracted wide attention with orders coming from USA and UK. Narayana Peesapathy is facing the challenge of creating awareness about the harmful health effects of plastic. He also feels that people are accustomed to using plastic products and will not find it easy to switch over to edible cutlery so easily. Bakey's has an online website through which it receives orders. In addition, they also have stalls at places like organic bazaars and exhibitions. Their edible cutlery are fully vegan, preservative free, trans fat free, and dairy free [8]. Of the energy it takes to produce 1 plastic utensil, Bakey's produces 100 sorghum based spoons, and in comparison with Corn, it produces 50 spoons. The energy costs are minimized through a semi-automatic process that minimizes waste and maximizes efficiency. In addition, the low water usage for each spoon (less than $2 \%$ of the weight per spoon), allows the spoons to have a very long shelf life of 2 years while maintaining their crispiness. Bakey's is now selling 1.5 million spoons in India every year. The flavours used by them include: sugar, ginger-cinamon, ginger-garlic, cumin, celery, black-pepper, mint-ginger, and carrot-beetroot. Figure 1 provides a sample of the edible tableware that is being produced by Bakey's.

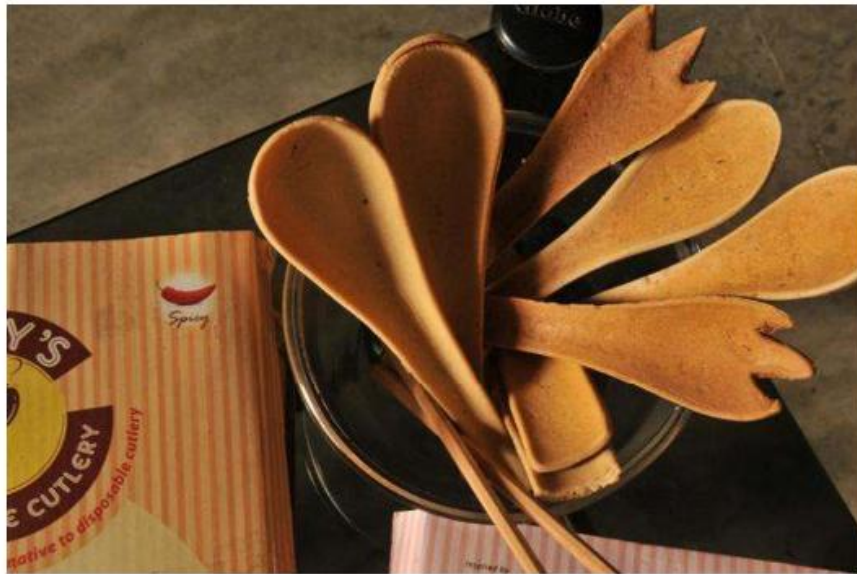

Fig. 1. Edible spoons, forks and chopsticks produced by Bakey's

A Delhi-based project called "Patradaya" makes edible bowls in three sizes [9]. The project helps the Afghan refugees in India.

The Defence Food Research Laboratory (DFRL) has been producing and promoting the technology related to edible cutlery [10].

\section{TAIWAN}

The Sugu Company of Taiwan has produced edible plates and other edible tableware items, and in 1986 claimed to have invented the "world's first range of edible tableware" as a means to replace disposable tableware [11].

\section{JAPAN}

Japanese designer Nobuhiko Arikawa of Rice-Design company has created edible tableware for Orto Cafe in Japan [12]. The plates, bowls and chopsticks are intended to replace disposable paper tableware. The pieces are made from hardtack, a biscuit dough made from flour, water and table salt, shortening, and yeast, no eggs or dairy products are used. They are baked like buns at a bakery so they are just as good as any bread for your meal. The biscuits will last for months as long as they are kept dry. The pieces have been put into production by Koratt bakery and café. Figure 2 provides an illustration of the plate, bowl and chopsticks that were produced by them. The bowls can be found at the The Edible Tableware shop sold at a price of 130 yen each (approximately 1.6 US\$) and are sold in sets of ten. The optimum thickness and texture of the edible bowl with a good flavor was determined by trial and error method. Since the bowls started being marketed in 2010, the response has been good at home and abroad. Around 50 countries outside Japan have ordered them for parties and events. At present, only the bowl is being marketed as the plates and spoons are deficient in withstanding normal eating utensil usage. The bowls produced by Rice-Design is found to last upto 45 days from the date of purchase. 
At present, only the bowl is being marketed. In reference to other items such as plates and spoons, they could not be marketed due to deficiency in withstanding normal eating utensil usage. It's good to know that bowls will last up to 45 days from purchase.

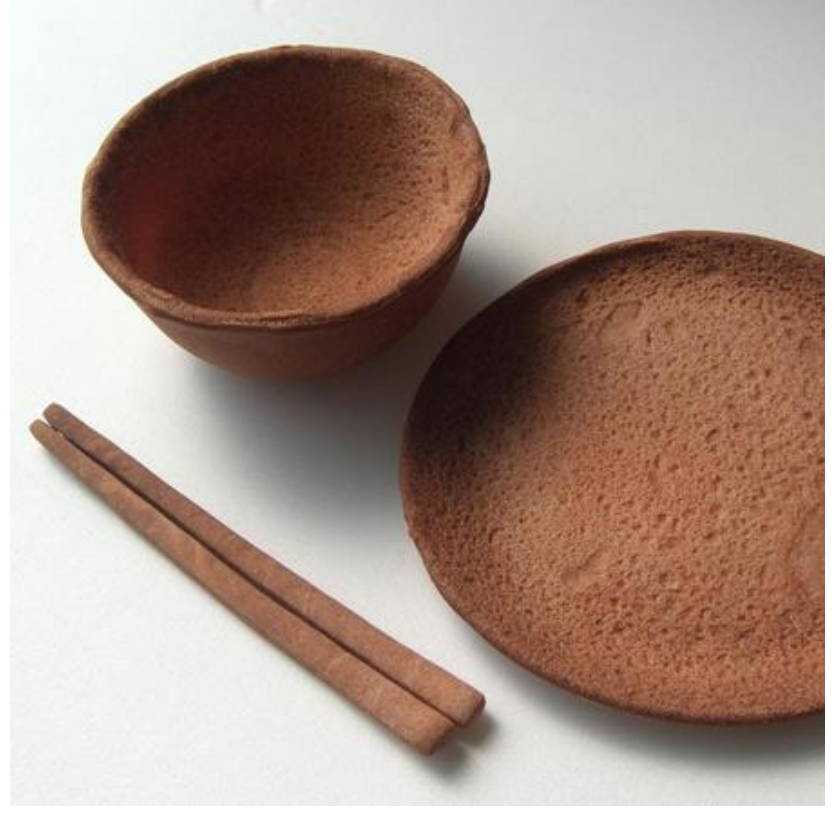

Fig. 2. Edible plate, bowl and chopsticks developed by Japanese designer Nobuhiko Arikawa, marketed by Rice-Design

In addition to Rice-Design, a small family business is being run by Sakakibara Katsuhiko under the name of Marushige Seika K.K. for developing a range of edible tableware [13]. Katsuhiko hails from a fishing town, Hekinan, 300 kilometers west of Tokyo. They develop plates using shrimp, salt and potato starch. The tableware, in addition to being sought by food vendors at baseball stadiums and local festivals, is receiving orders from overseas. The plates and bowls come in variety of oval or rectangular shapes and are tougher than they appear. It can hold water upto 30 minutes. Initially the company was making ordinary monaka crust, made of wheat, but since its performance was poor when wet, the company sought for shrimp crackers. The e-tray products even include plates flavoured to taste like sweet potato or onion. Their plan is to provide edible plates for the Tokyo Olympic games to be held in 2020. They are also planning to produce edible knives and forks in the future with the view of cutting down waste production in his town.

Small cups made of edible seaweed are being produced by Yokohama based food packaging company named Honest [14]. The cups, about $2 \mathrm{~cm}$ deep and $4 \mathrm{~cm}$ in diameter at the base are especially popular among mothers with young children as they can be put to various uses while packaging lunch boxes. Initially, the cups were intended to be sold only in the restaurants but due to the high consumer demand, an online shop was opened in 2007. Since then the company has produced edible cups with new flavours and resealable packaging that prevents the humidity from softening of the seaweed. The Honest company president Masaki Miyata said that the company only uses Japanese seaweed and is receiving more orders from overseas including the United States of America.

Research on producing edible tableware with 3-D printers is also gaining momentum thesedays. Keio University in Tokyo is involved in a project of make eating utensils like chopsticks, spoons and cups with rice flour, and has built an experimental 3-D printer for that purpose. They even intend to make toys that are eatable for the children in the daycare centers and nursing homes.

\section{BELGIUM}

A couple of Belgian designers have come up with a new range of edible food containers that are eco-friendly and tasty [15]. The young entrepreuners - Helene Hoyois and Thibaut Gilquin, are making containers using potato starch, water and oil. These containers are tough enough to retain all sorts of food and sauces, and also digestable. They can be disposed off if not eaten as they are biodegradable. They received financial support from a corporation called Wallonia Creative to set a company called "Do Eat", $30 \mathrm{~km}$ away from Brussels with over 30 employees. They plan to make glasses, cutleries and bowls in the future. Figure 3 shows the edible containers that are being produced by the "Do Eat" company.

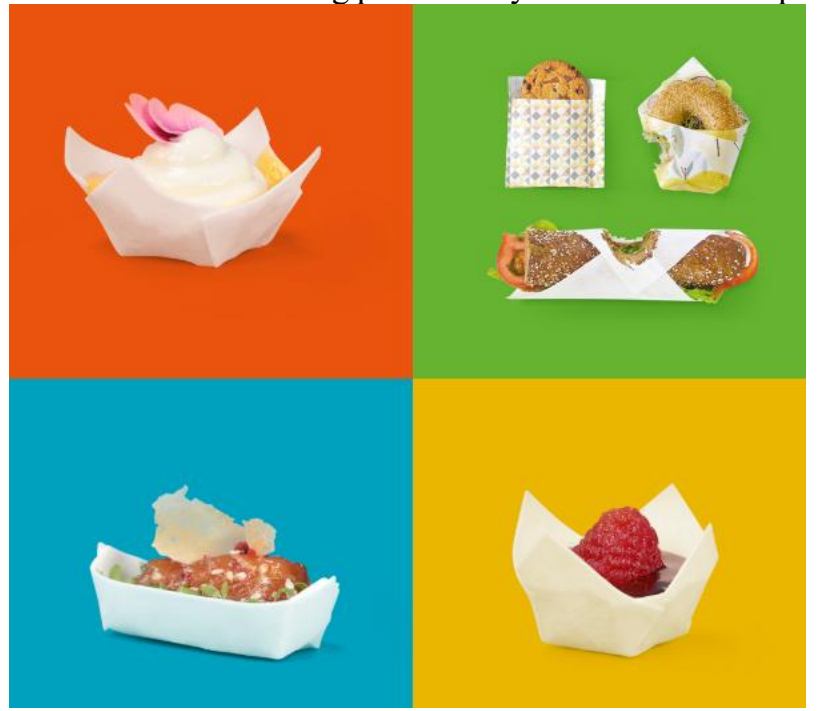

Fig. 3. Edible containers made by Do Eat company.

\section{POLAND}

Biotrem's wheat bran tableware production process was founded by Mr. Jerzy Wysocki. Their modern and booming production facility offers a wide range of fully biodegradable tableware and cutlery produced from natural and edible wheat bran. From 1 ton of pure, edible bran they produce 10,000 units of plates or bowls. The tableware can be used to serve both hot and cold meals. They can even be used in classic ovens or microwave ovens. The sizes of the tableware include: $28 \mathrm{~cm}, 24 \mathrm{~cm}$, and $20 \mathrm{~cm}$ diameter plates, $20 \mathrm{~cm}$ diameter bowls, $24 \times 16 \mathrm{~cm}$ oval bowl. They also take orders for specific sizes and shapes with a maximum diameter of $28 \mathrm{~cm}$. Biotrem has centers in Denmark, Italy. Norway, UK, France, Netherlands, Austria, Hungary, Sweden and USA. Figure 4 shows the plates of various sizes that are being sold by Biotrem. 


\section{Eco-Friendly and Edible Waste Cutlery for Sustainable Environment}

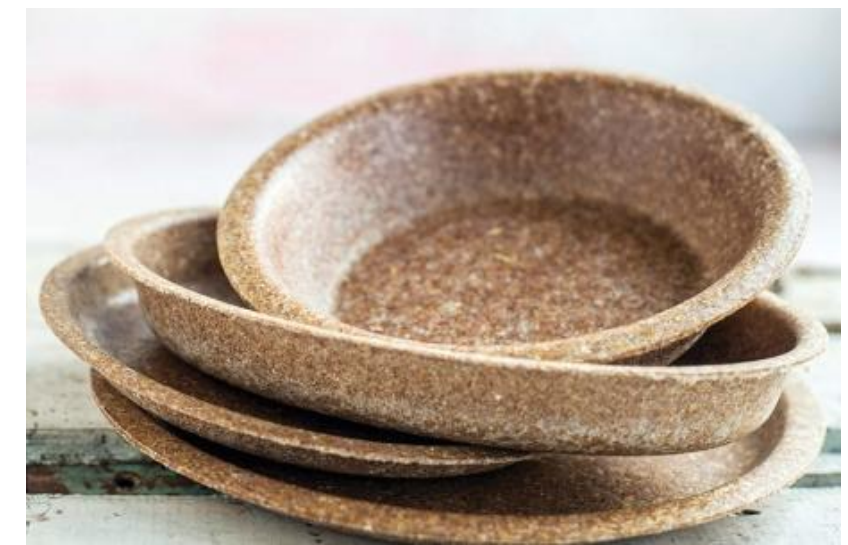

Fig. 4. Edible plates manufactured by Biotrem

\section{SOUTH AFRICA}

The company MunchBowls Private Limited was founded by Georgina de Kock and established in Western Cape, South Africa, since 2011 [16]. The produce edible, crisp wheat bowls, known as Munch Bowls. The bowl is eco-friendly, edible alternative to plastic and polystyrene. The edible crisp wheat bowls can hold meals such as stir-fries and salads, etc. for more than 60 minutes. Stews and thick soups can be held for 30 minutes or more, with the bowl maintaining its crispiness and shape. It has a shelf life of 15 months and the crispiness can be restored by keeping in the oven for 3-5 minutes at $70-100^{\circ} \mathrm{C}$. The ingredients used for making this bowl include flour, bran, sugar and oil. Its fully vegan, with no artificial colourants and with no yeast.

\section{USA}

Loliware co-founders Chelsea Briganti and Leigh Ann Tucker combined their concern for the environment and passion to invent a new category of sustainable cup [17]. This was launched in March 2015. Loliware is the first and only edible disposable cup (Figure 5), which is $100 \%$ plastic-free, gluten-free, gelatin-free, non-GMO, all natural, safe, and non-toxic. They are biodegradable and also edible. It is made from seaweed called agar, organic sweeteners and flavors and colors derived from fruits and vegetables. The currently used flavor is grapefruit and yuzu. Food can be served at room temperature, chilled or frozen. Loliware has consumers in 40 countries across 6 continents. These cups can be thrown in the grass or disintegrated in a matter of minutes with hot water. The only concern with these edible cups is the cost. A pack of 4 cups cost $\$ 11.95$. As of now, they are not available outside the US.

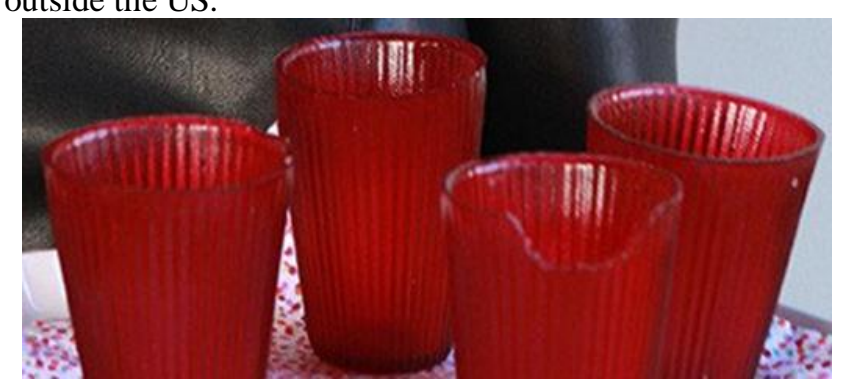

Fig. 5. Edible cups manufactured by LOLIWARE

ChocAmo company produces edible cookie cups. Founded by a young entrepreneur, Michelle Silberman, the company produces an innovative edibleware using highest quality ingredients, cookie counters and cookie cutters. The company sells the products through an online store. Figure 6 provides a picture of the cookie cup developed by the company.

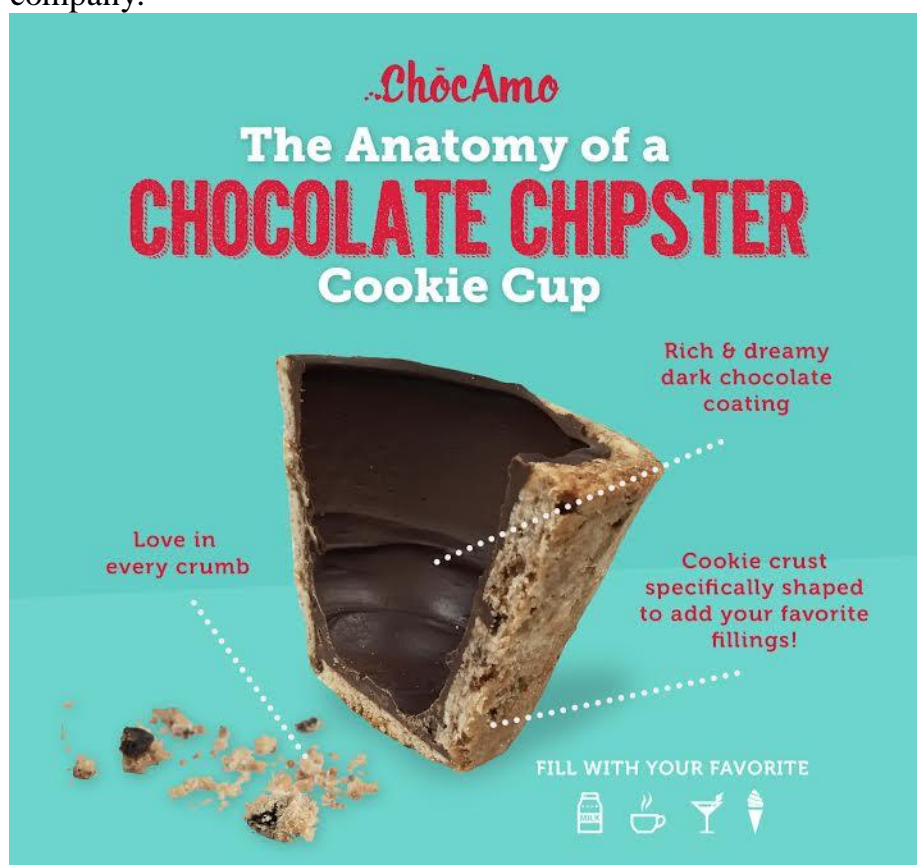

Fig. 6. Anatomy of the cookie cup manufactured by ChocAmo, founded by Michelle Silberman

\section{FRANCE}

The utensils at French patisserie Poilane are crackers and cookies that are used to enjoy the company's hors d'oeuvres and desserts [18]. A curry flavoured fork is the perfect complement for the mango chutney or hummus, while a shortbread cookie spoon becomes a garnish for the ice cream or espresso stirrer. Figure 7 illustrates the edible forks that being supplied at Poilane.

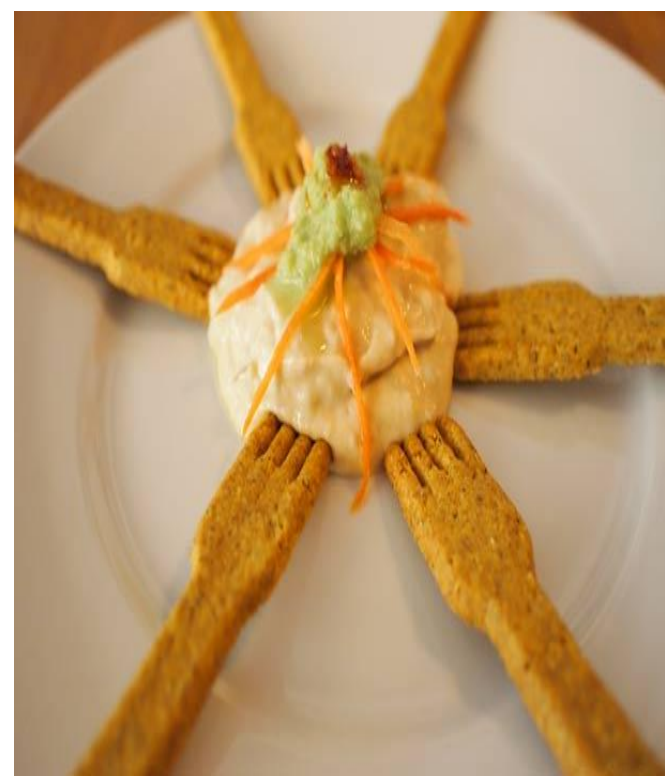

Fig. 7. Edible fork manufactured by Poilane

\section{Published By:}




\section{Individual designers}

This section deals with edible tableware created by individuals from a perspective other than that of commercialization. These edible products were made by them from their artistic or experimental skills [19]. Dutch artist Geke Wouters has created a stunning collection of paper thin edible bowls made from carrots, peppers, beetroot, leeks, tomatoes, and other vegetables. Each bowl was made using a proprietary drying and forming process that converts the organic materials into the paper thin layers, providing an intricate cellular structure. None of these bowls look alike. Since it was only produced from the artistic perspective, its ability to hold fluid is not assured. Figure 8 provides a sample of the artistic edibleware created by Wouters.

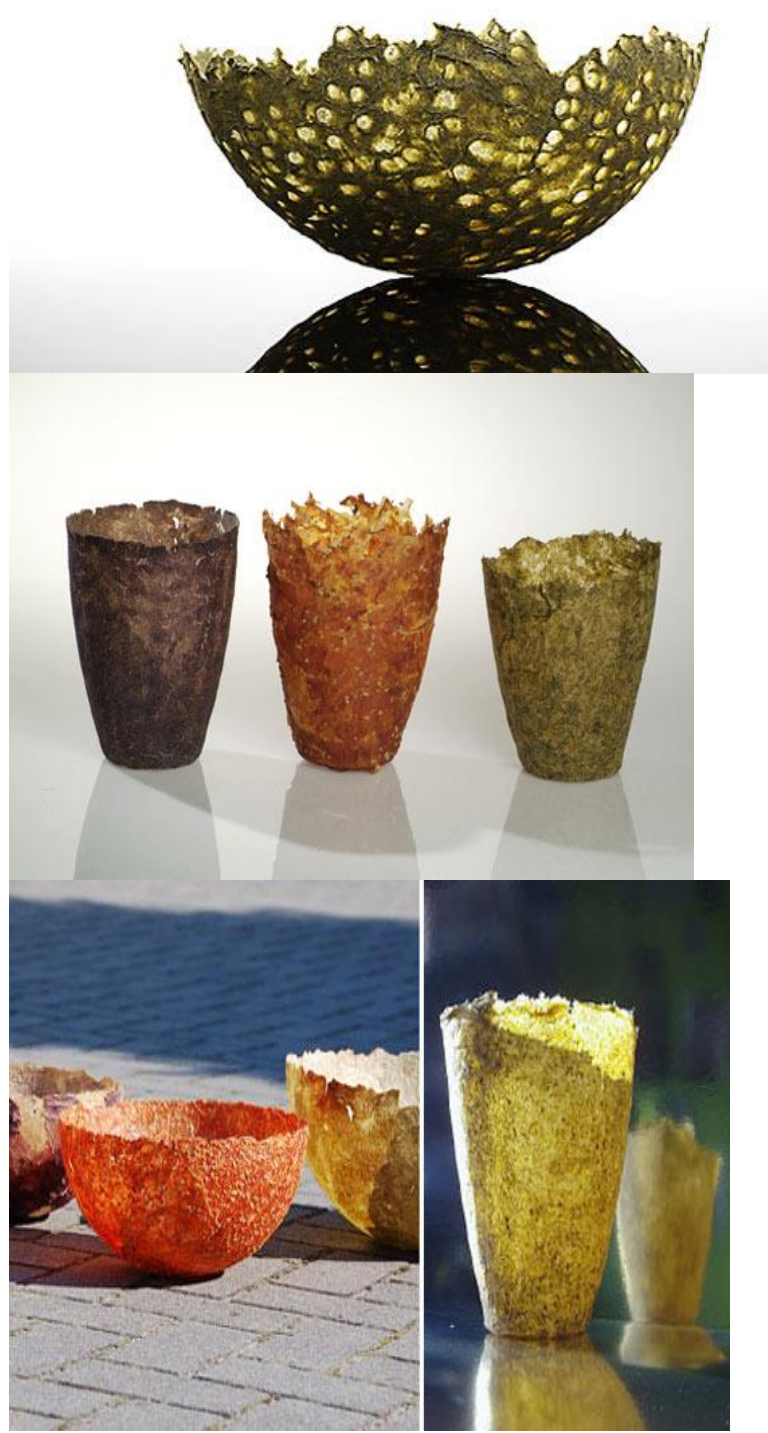

Fig. 8. Artistic edible bowl created by Wouters using vegetables.

A set of beautiful fragile edible cups and saucers were designed by Padiglione-Italia [20]. They are made out of sacramental bread used in the Catholic churches. Figure 9 provides a sample of the cups and saucers produced by the designer.

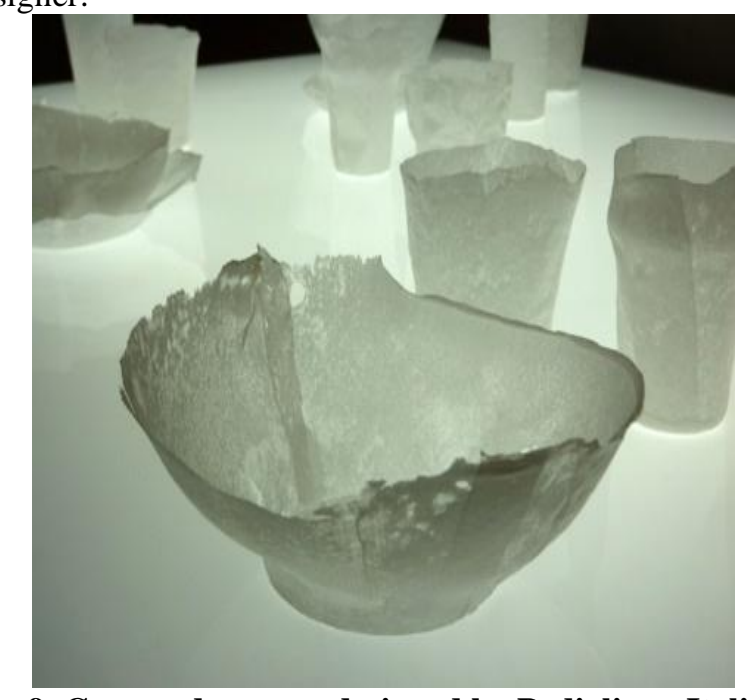

Fig. 9. Cups and saucers designed by Padiglione-Italia. Michelle Ivankovic makes plates using pasta [21]. Her ingredients include flour, water, egg, plant based colour and gelatin. A coating of water resistant gelatin is added to the top of the surface to ensure functionality. Figure 10 illustrates some of the plates that were designed by her for a fair in 2013.

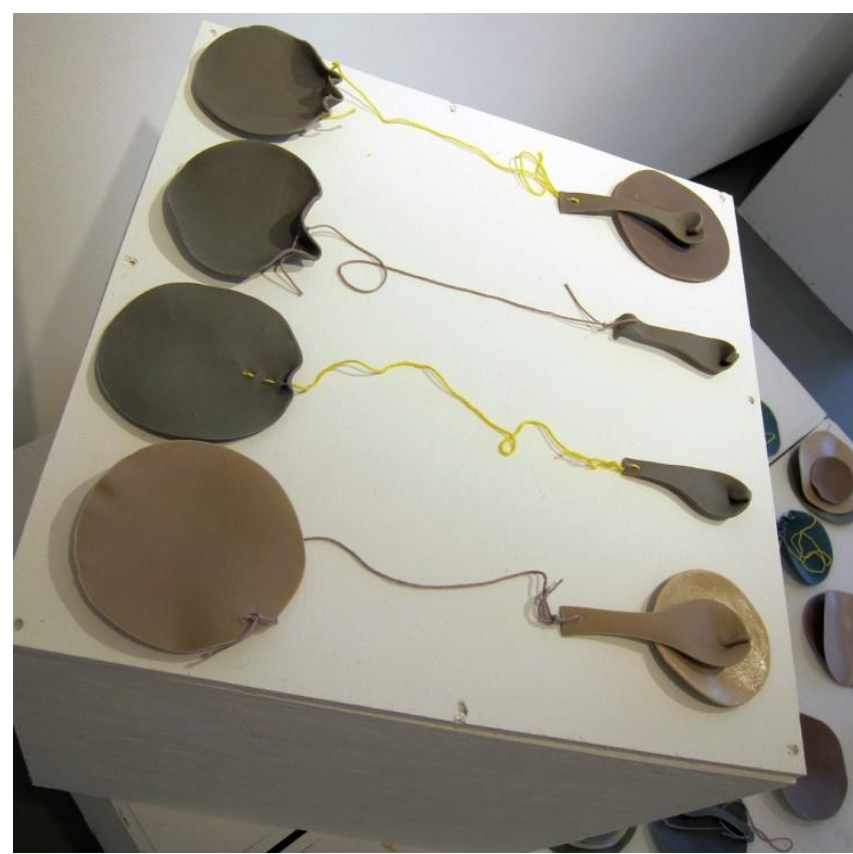

Fig. 10. Plates made out of pasta, designed by Michelle Ivankovic

The edible bowls made by Diane Leclair Bisson are a part of the edible project and are made of fruits and vegetables [22]. They accommodate hot and cold foods. Figure 11 shows the bowls developed by her. 


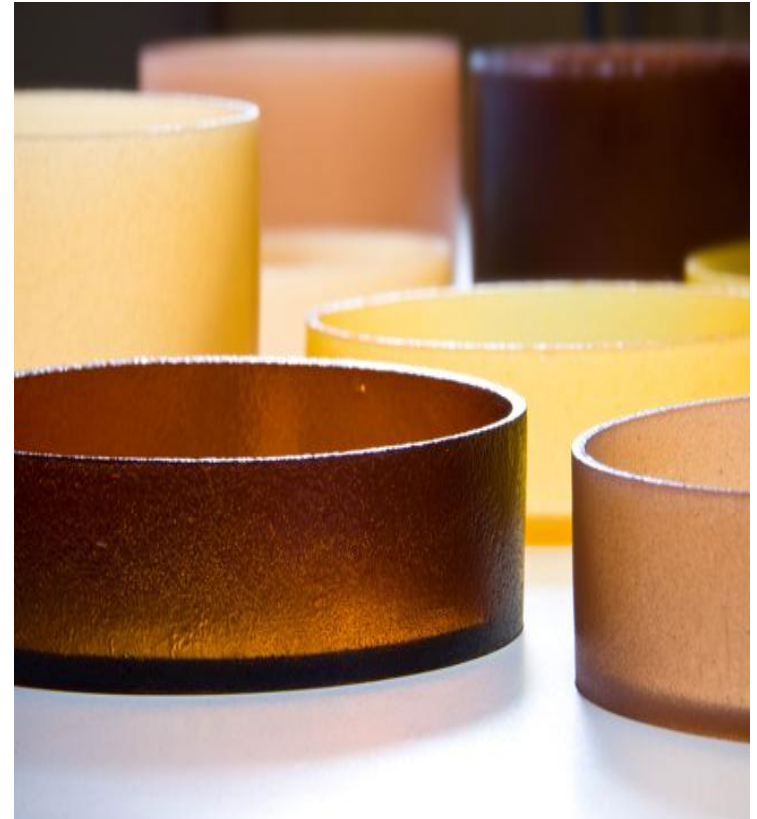

Fig. 11. Edible bowls made from vegetables and fruits, designed by Diane Leclair Bisson

The latest project by students from the Piet Zwart Institute in Rotterdam has reshaped the kitchen appliances into tools for making biodegradable and edible tableware [23]. The altered appliances called as rollware are a set of traditionally looking rolling pins with different shapes cut out from the wood that can be used to make edible tableware by cutting patterns into the dough. The range also includes Extrudough, a collection of biodegradable tableware made with a modified meat grinder. The figure 12 below gives a sample of the tools that have been designed by the students for the preparation of edible tableware.

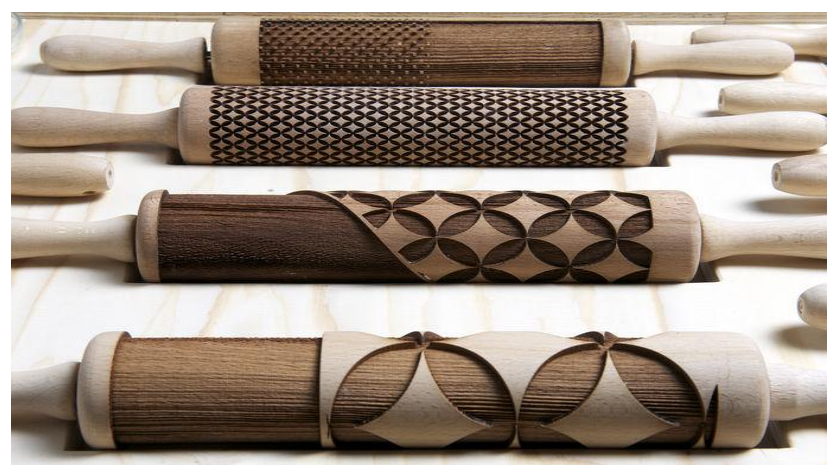

Fig. 12. Tools for making edible bowls, designed by the students of Piet Zwart institute of Rotterdam

\section{INFERENCE FROM LITERATURE REVIEW}

Environmental pollution is a cause of concern for everyone, especially the disposal of plastic plates and utensils has tremendous increased over the decades. Some of them are working on providing an alternative for this never dying problem. While some companies (Bakey's, Rice-Design, Poilane, etc.) are selling only spoons and forks, some others like Biotrem are selling plates, and others like Loliware are selling edible cups. Munchbowls, on the other hand, is focused on selling edible bowls. It is evident from the literature that there is no single company/organization that is selling all types of utensils. Table I below provides a comparison of the products sold by different entrepreneurs.
An alternative solution has been proposed by a few but whether people are interested to adapt themselves to the edible tableware is something which needs to be investigated. People in some countries, especially the developed countries, are boldly embracing the new move, while in some other countries, the scenario is different. This is evident from the fact that companies loacated in Asia are receiving orders from countries located in other continents. People in the developing countries are not so eager to purchase the edible tableware since they are used to plastic utensils and it might take some time for the change to occur.

The cost of production of the edible tableware is another aspect of discussion. Bakey's founder Narayana Peesapathy feels that although many of them are purchasing his products, the cost of a single spoon is still higher than the cost of a plastic spoon. He wants to bring down the cost by encouraging the production of millets. The cost of the cups sold by Loliware is also conceived to be too high by the customers. Therefore, unless the cost of the edible tableware becomes cheap, customers will not choose to buy these utensils. Finally, we will be facing the same scenario of having to manage the environmental pollution due to plastic utensils.

Futhermore, edible tableware market opens up a new opportunity for the farmers in the fields. They have the choice of producing the crops that are being used by these corporates, which will in turn increase their returns. Moreover, its not just the farmers who are going to benefit from the production of edible tablware but even the utensil manufacturers have an opportunity to expand their market. The students from the Piet Zwart institute in Rotterdam have made roller pins that can be used to manufacturing edible tableware.

Artists are nowadays interested in carving out articles from biodegradable materials like fruits and vegetables. Literature shows that even they are carrying the intention of protecting the environment from rapid degradation of solid waste disposal. Although, they are not interested in marketing the edible tableware, nevertheless, they want to create awareness among the people that edible cups and saucers is a potential source of replacement for plastic spoons and cups.

\section{CONCLUSION}

Plastic waste disposal is a major cause of concern. Among plastic wastes, disposal of plastic utensils is significant and has a tremendous impact on the surrounding environment. As an alternative to plastic utensils, some entrepreneurs have developed edible tableware. This paper provides a review of the edible tableware developed and marketed by various entrepreneurs around the world. Even the minor efforts of the individual artists towards making of edible tableware have been reviewed. There is a lot of scope for cutting edge research in this domain. The entrepreneurs claim that these tableware can hold liquids only upto 15-20 minutes, after which they will melt. Children of young age may want to consume their meals for a longer duration, for which the tableware should be able to sustain the liquids for a longer duration.

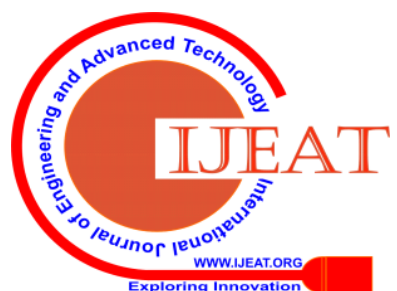


Research also needs to be carried out to identify the materials with least absorption capacity since there is a possibility of the tableware absorbing the soups and liquids being poured in them. In addition, the shelf time of these materials is also another aspect that needs to be studied. The rate of degradation of the edible tableware is also important feature. Rapid degradation will surely benefit the environment and enhance its sustainability. Furthermore, since the tableware is edible, the disposed tableware could be a source of food for micro-organisms and insects in the soil. In such cases, it is necessary to carry out research on the safety of consumption by such living species. Finally, it's a herculean task to develop cost-effective moulds for preparing different types of edible utensils under a single roof. Moreover, the labor required for operation and maintenance of such units would be another challenge. This is where we feel that research on automating the systems would play a vital role. Although, there are many hurdles, in terms of the cost, materials, labor, biodegradability, longetivity, etc., edible tableware is certainly a potential source for environmental protection and sustainable development.

\section{REFERENCES}

1. A.A. Abdulrasoul, S.S. Bakari, "Challenges and problems of solid waste management in three main markets in Zanzibar", Advances in recycling and waste management, Vol. 1, No. 2, 1000101-1000109, 2016.

2. I.A. Al-Khatib, H.A. Arafat, T. Basheer, H. Shawahneh, H., A. Salahat, J. Eid, W. Ali, "Trends and problems of solid waste management in developing countries: A case study in seven Palestinian districts," Waste Management, Vol. 27, No. 12, 1910-1919, 2007.

3. M. Berkun, E. Aras, S. Nemlioglu, Country report disposal of solid waste in Istanbul and along the Black Sea coast of Turkey. Waste Management, Vol. 25, pp. 847-855, 2005.

4. G.E. Blight, C.M. Mbande, "Some problems of solid waste management in developing countries," Journal of solid waste technology and management, Vol. 23, No.1, pp. 19-27, 1996.

5. EnactusKMC - Changing Lives - Creating Impact - Delhi". Enactus KMC - Changing Lives - Creating Impact - Delhi

6. Edible cutleries of DFRL on display at Aero India Show - Star of Mysore.

\section{AUTHORS PROFILE}

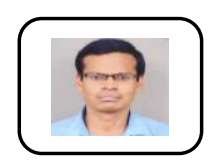

Dr. N. Natarajan is working as an associate professor in the department of Civil Engineering, Dr. Mahalingam College of engineering and technology, Pollachi, Tamil $\mathrm{Nadu}$, India. His research interests include contaminant transport modeling, environmental pollution, and water resources.

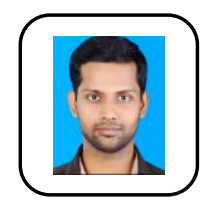

Dr. M. Vasudevan is working as an assistant professor in the department of Civil Engineering, Bannari Amman Institute of Technology, Sathyamangalam, Tamil Nadu, India. His research interests include solid waste management, environmental pollution, and wastewater treatment.

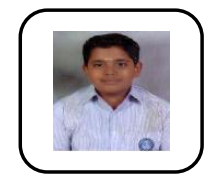

Mr. V. Vivekk Velusamy is an undergraduate student pursuing her bachelors degree in Civil Engineering at Dr. Mahalingam college of engineering and technology, Pollachi, Tamil Nadu, India.

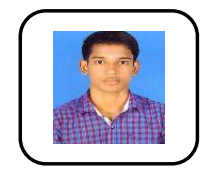

Mr. M. Selvaraj is an undergraduate student pursuing her bachelors degree in Civil Engineering at Dr. Mahalingam college of engineering and technology, Pollachi, Tamil Nadu, India. 
Eco-Friendly and Edible Waste Cutlery for Sustainable Environment

TABLE - I: Comparison of products sold by different entrepreneurs

\begin{tabular}{|c|c|c|c|c|c|c|c|}
\hline Description & Bakey's & Rice-Design & Do Eat & Biotrem & Munchbowls & Loliware & ChocAmo \\
\hline Origin & India & Japan & Belgium & Poland & South Africa & USA & USA \\
\hline Entrepreneur & $\begin{array}{l}\text { Narayana } \\
\text { Peesapathy }\end{array}$ & $\begin{array}{l}\text { Nobuhiko } \\
\text { Arikawa }\end{array}$ & $\begin{array}{l}\text { Helene } \\
\text { Hoyois and } \\
\text { Thibaut } \\
\text { Gilquin }\end{array}$ & $\begin{array}{l}\text { Jerzy } \\
\text { Wysocki }\end{array}$ & $\begin{array}{l}\text { Georgina de } \\
\text { Kock }\end{array}$ & $\begin{array}{l}\text { Chelsea } \\
\text { Briganti } \\
\text { and } \\
\text { Leigh } \\
\text { Ann } \\
\text { Tucker }\end{array}$ & $\begin{array}{l}\text { Michelle } \\
\text { Silberman }\end{array}$ \\
\hline $\begin{array}{l}\text { Type of } \\
\text { cutlery } \\
\text { produced }\end{array}$ & $\begin{array}{l}\text { Spoons, fork } \\
\text { and } \\
\text { chopsticks }\end{array}$ & $\begin{array}{l}\text { Plate, bowl } \\
\text { and } \\
\text { chopsticks }\end{array}$ & Containers & $\begin{array}{l}\text { Bowls and } \\
\text { plates }\end{array}$ & Bowls & Cups & Cookie cups \\
\hline Cost & $\begin{array}{l}\text { A pack of } \\
100 \text { spoons } \\
\text { cost } 300 \\
\text { rupees } \\
\text { (approx. } \\
4.62 \quad \text { US } \\
\text { cents) }\end{array}$ & $\begin{array}{l}\text { A bowl costs } \\
130 \\
\text { yen(approx. } \\
1.6 \$ \text { ) }\end{array}$ & $\begin{array}{l}\text { A pack of } \\
25 \quad \text { costs } \\
9.95 \\
\text { pounds ( } \\
\text { approx. } \\
13.78 \$)\end{array}$ & $\begin{array}{l}\text { A pack of } \\
10 \quad \text { plates } \\
\text { of size } \\
20 \mathrm{~cm} \\
\text { costs } 3.2 \\
\text { pounds } \\
\text { (approx.. } \\
4.43 \$ \text { ) }\end{array}$ & - & $\begin{array}{l}\text { A pack of } \\
4 \quad \text { costs } \\
11.95 \$\end{array}$ & $\begin{array}{l}\text { A box of } 6 \\
\text { would range } \\
\text { from } 25 \text { to } \\
30 \$\end{array}$ \\
\hline
\end{tabular}




\begin{tabular}{|c|c|c|c|c|c|c|c|}
\hline $\begin{array}{l}\text { Centers } \\
\text { elsewhere }\end{array}$ & - & - & - & $\begin{array}{l}\text { Denmark,I } \\
\text { taly, } \\
\text { Norway, } \\
\text { UK, } \\
\text { France, } \\
\text { Netherlan } \\
\text { ds, } \\
\text { Austria, } \\
\text { Hungary, } \\
\text { Sweden } \\
\text { and USA }\end{array}$ & - & - & - \\
\hline $\begin{array}{l}\text { Orders from } \\
\text { abroad }\end{array}$ & Yes & Yes & Yes & $\begin{array}{l}\text { Centers } \\
\text { are located } \\
\text { in } \\
\text { different } \\
\text { countries }\end{array}$ & Yes & Yes & Yes \\
\hline Shelf life & $\begin{array}{l}2 \text { years if } \\
\text { sealed }\end{array}$ & - & 6 months & - & 15 months & $\begin{array}{l}12 \\
\text { months if } \\
\text { sealed }\end{array}$ & - \\
\hline $\begin{array}{l}\text { Longevity of } \\
\text { holding } \\
\text { liquids }\end{array}$ & $\begin{array}{l}\text { Spoons get } \\
\text { soggy after } \\
10 \text { minutes }\end{array}$ & - & $\begin{array}{l}2 \text { hours or } \\
\text { less }\end{array}$ & $\begin{array}{l}\text { Hot liquid } \\
\text { thick } \\
\text { soups upto } \\
30 \\
\text { minutes } \\
\text { and hot } \\
\text { thin } \\
\text { liquids } \\
\text { upto } 20 \\
\text { minutes }\end{array}$ & 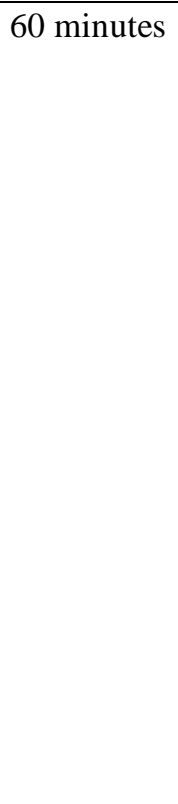 & - & - \\
\hline
\end{tabular}


Eco-Friendly and Edible Waste Cutlery for Sustainable Environment

\begin{tabular}{|c|c|c|c|c|c|c|c|}
\hline $\begin{array}{l}\text { Carbon } \\
\text { footprint }\end{array}$ & & & & $\begin{array}{l}1.3 \text { to } 1.6 \\
\mathrm{~g} \quad \text { of } \\
\mathrm{CO}_{2} / \mathrm{kg}\end{array}$ & - & - & - \\
\hline $\begin{array}{l}\text { Type of food } \\
\text { that can be } \\
\text { served }\end{array}$ & $\begin{array}{l}\text { Hot and cold } \\
\text { liquids }\end{array}$ & - & $\begin{array}{l}\text { Hot or cold } \\
\text { preparation } \\
\text { s but not } \\
\text { water and } \\
\text { alcohol }\end{array}$ & $\begin{array}{l}\text { Hot and } \\
\text { cold } \\
\text { liquids }\end{array}$ & $\begin{array}{l}\text { Hot and room } \\
\text { temperature } \\
\text { liquids }\end{array}$ & $\begin{array}{l}\text { Only } \\
\text { room } \\
\text { temperat } \\
\text { ure and } \\
\text { cold } \\
\text { liquids }\end{array}$ & - \\
\hline $\begin{array}{l}\text { Placing in } \\
\text { oven }\end{array}$ & - & - & Safe & Safe & - & - & - \\
\hline
\end{tabular}

